\title{
Endocrine System Part
}

National Cancer Institute

\section{Source}

National Cancer Institute. Endocrine System Part. NCI Thesaurus. Code C13029.

Any component of the tissues capable of secreting hormones. 